\title{
Complications of Genital Piercings
}

Kara A Dalke1, Lydia Fein ${ }^{2}$, Lawrence C Jenkins ${ }^{3}$, Jorge R Caso ${ }^{4}$ and Christopher J Salgado ${ }^{5 *}$

${ }^{1}$ Department of Obstetrics and Gynecology, University of Miami Miller School of Medicine, Miami, Florida, USA

${ }^{2}$ University of Miami Miller School of Medicine, Miami, Florida, USA

${ }^{3}$ Department of Urology, University of Miami Miller School of Medicine, Miami, Florida, USA

${ }^{4}$ Department of Urology, University of Miami Miller School of Medicine, Miami, Florida, USA

${ }^{5}$ Department of Plastic Aesthetic and Reconstructive Surgery, University of Miami Miller School of Medicine, Miami, Florida, USA

\begin{abstract}
Genital piercing has become a "social reality" in our present day culture. Its practice is not limited by sexual preference, gender, age or background. There are a variety of complications, acute and chronic, related to the piercing of both male and female genitalia that can affect the individual and his or her sexual partner. It is therefore imperative for healthcare practitioners to be aware of the various genital piercing practices, the types of jewelry used and the potential complications which may arise in order to appropriately counsel and manage those patients with complications relating to their genital piercings.
\end{abstract}

Keywords: Genital piercing; Body piercing; Complications; Penile piercing; Clitoral piercing

\section{Introduction}

Genital piercing is not a new phenomenon, nor is it of western origin. There has been anthropological and literary evidence of genital piercing in cultures throughout different eras in history. "De Medicina", the medical treatise by Aulus Cornelius Celsus during the $1^{\text {st }}$ century $\mathrm{BCE}$ is considered to be the best surviving text on Alexandrine medicine and describes male genital piercing techniques in detail [1]. "The Kama Sutra," believed to have been written by the Sanskrit scholar, Vatsyayana, between 100-600AD makes reference to penile piercing in the second chapter [2]. In ancient Mayan civilization, there is evidence of royalty piercing their genitals as part of religious ceremonies as early as 700AD [2,3]. The Victorian era had Prince Albert, Queen Victoria's husband, who allegedly wore a penile ring to secure his genitals to the right or left leg of the extremely tight pants he wore, as was the fashion of that period. Currently, the "Prince Albert" is reported to be the most popular style of penile ring [2,4-6].

In more contemporary societies, there is evidence of women with labial piercings in post-World War II Germany [2]. In the United States (US), body piercing was popularized within the past fifty years by Fakir Musafar, who through his Modern Primitive movement, established it as "body art," promoting the use of "piercing, implants, tattooing, and branding as they were used in primitive societies to experience visual, emotional, and sensual expressions of the body that life would not normally provide" [7].

While genital piercing is not a new phenomenon, it has only started appearing in the US health care literature in the mid-1990s. Verylittle has been published on genital piercing, and prevalence rates remain elusive [6]. The trend of obtaining genital piercings for aesthetic and sexual reasons continues to increase and is not limited by age, gender, socioeconomical background, or sexual preferences. It has become a "social reality" of our present day culture, and physicians may be requested to place genital piercings by their patients or to treat complications. Therefore, healthcare practitioners should be aware of these practices, the type of jewelry that is used, the available research in this area and the possible complications that can arise. Additionally, healthcare practitioners should also be able to elicit an appropriate sexual history, provide counseling and competently manage complications and side effects of genital piercings [2].
Currently, when complications arise with their genital piercings, men and women are more likely to seek nonmedical advice from the Internet or a piercer rather than a trained healthcare provider. This is in part due to lack of confidence in clinician knowledge regarding piercings and fear of being told to immediately remove the piercing when this may not be necessary [5,6]. These apprehensions place men and women at a higher risk for delays in receiving appropriate medical care for piercing-related complications [4].

Body piercing is a largely unregulated industry in the United States [8]. Existing legislation varies considerably by state, as there is no federal mandate regulating body art [5]. Piercers are generally unlicensed, and many of the techniques are self-taught or learned as "hands on" apprenticeships [9]. The Association of Professional Piercers (APP) has a health, safety, and education web page that can be accessed at: http:// www.safepiercing.org. This resource provides information and links to sites addressing anatomy, infection control, and governmental sites related to health and safety, disease prevention, and health and human services [7]. Piercing of the female genitalia remains controversial as the WHO has defined four types of female genital mutilation (FGM): Type IV includes 'pricking, piercing or incising of the clitoris and/or labia', therefore it is argued that a person performing female genital piercing could be guilty of Type IV FGM even though the services are sought out and requested by the woman [2]. Despite these considerations, many women still have their genitals pierced.

\section{Motivations for Genital Piercings}

While lay literature generally portrays genital piercings as a source of sexual pleasure and aesthetic satisfaction for those who possess them, medical publications have historically painted discriminatory pictures

*Corresponding author: Christopher J Salgado, Department of Plastic Aesthetic and Reconstructive Surgery, 1120 NW 14th St, Clinical Research Building 4th floor Miami, Florida 33136, USA, Tel: 305-243-4500; Fax: 305-243-4535; E-mail: salgado_plastics@hotmail.com

Received October 03, 2013; Accepted November 06, 2013; Published November 11,2013

Citation: Dalke KA, Fein L, Jenkins LC, Caso JR, Salgado CJ (2013) Complications of Genital Piercings. Anaplastology 2: 122. doi: 10.4172/2161-1173.1000122

Copyright: $\odot 2013$ Dalke KA, et al. This is an open-access article distributed under the terms of the Creative Commons Attribution License, which permits unrestricted use, distribution, and reproduction in any medium, provided the original author and source are credited. 
of genitally pierced persons. Despite supporting evidence, those with body piercings, in particular genital piercings, have at various times been labeled as "born criminal," $[6,10]$ more prone to have sexually transmitted infections (STIs), $[6,11]$ and as sadomasochistic $[6,12,13]$. However, these labels have been largely based on postulated theories and preconceived assumptions. In a study by Willmott in 2001, a cohort of women with various body piercings who presented at an STI clinic were compared to non-pierced women at the same facility, and no relationship was found between piercing status and socio-economic status, method of contraception, multiple partners, or presence of genital infection [14].

In the more recent medical literature, studies have been published that corroborate the assertion of the lay literature, reporting that persons with genital piercings find them to be a source of sexual pleasure. Furthermore, these studies demonstrate that genitally pierced individuals do not generally fall into demographic subsets of criminals or fetishists as has been previously assumed. The majority of respondents of four surveys published in medical or nursing journals were college-educated and gainfully employed. They sought genital piercings to enhance sexual expression and improve sexual pleasure and reported that these desires were achieved following piercing $[4,6,15,16]$. Two surveys asked about sexual practices and drug use and both found that the majority of respondents were in monogamous relationships, had never been diagnosed with an STI, and reported no drug use $[4,15]$.

Another survey, conducted by Body Art magazine and referenced in the British Medical Journal, revealed that among pierced respondents, $58 \%$ were married and less than $20 \%$ considered themselves to be sadomasochistic, fetishist, or exhibitionist $[17,18]$. The respondents with genital piercings reported being pierced for aesthetic and sexual pleasure purposes. In addition, a case study published in Obstetrics and Gynecology documented the enhancement of sexual pleasure following genital piercing. In the study, a previously anorgasmic woman was able to achieve daily orgasm following clitoral piercing [9].

\section{Types of Piercings and Common Jewelry}

There are three main types of jewelry used for genital piercing: the barbell, which is a straight bar with a ball threaded onto one of the ends that unscrews (also called a banana bar); the curved barbell; and the captive ring, an open ring in which a ball is inserted between two small dimples. It is removed by placing the tip of fine pliers in the ring and opened, which will cause the ball to fall out [7]. Medical professionals should be familiar with how these piercings can be removed. In the setting of the operating room, a piercing left in place on the surgical site when prepped does not guarantee complete sterility as part of the piercing remains within the tissue. Additionally, an unprotected metal piercing may ground the patient and cause a second-degree burn during electrocauterisation $[3,7]$.

In regards to the types of genital piercing, they are numerous. Some of the most popular are listed in Tables 1 and 2 [2-5,7,9] and can be seen in Figures 1 and 2.

\section{Complications}

Complications of genital piercing are numerous and quite common. In a study of 445 men with genital piercings, 53\% reported having at least one complication post procedure [4]. Another study that surveyed 84 men and women with genital piercings found that $52 \%$ reported at least one health-related problem following their piercings [6]. These complications may be related to the piercing process itself, or the persistence of a foreign body in the tissue [19-21]. In general, complications of genital piercings can be broadly divided into three categories: structural, infectious, and partner related.

\section{Structural Complications}

As described in Table 3, structural complications can be vast and vary by gender. Most of these complications relate to anatomical trauma and are either acute, such as bleeding, or chronic, such as scar/ keloid formation.

\begin{tabular}{|c|c|c|c|}
\hline NAME & DESCRIPTION & HEALING TIME & ADDITIONAL INFO \\
\hline $\begin{array}{l}\text { Foreskin/Oetang } \\
\text { (Figure 1a) }\end{array}$ & $\begin{array}{l}\text { Often done on both sides of foreskin with small rings that can be } \\
\text { connected, deliberately making intercourse difficult. }\end{array}$ & 6-8 weeks & $\begin{array}{l}\text { Done when the penis is flaccid. Can be used as a 'chastity } \\
\text { belt' when lateral foreskin linked to other side }\end{array}$ \\
\hline $\begin{array}{l}\text { Dydoe } \\
\text { (Figure1b) }\end{array}$ & Single or multiple studs/bars at the coronal ridge & 3-4 months & Done on circumcised males \\
\hline $\begin{array}{l}\text { Ampallang, "crossbar", } \\
\text { "palang" } \\
\text { (Figure 1c) }\end{array}$ & $\begin{array}{l}\text { Horizontally through head of penis above or below the urethra, } \\
\text { sometimes through the urethra }\end{array}$ & 6-12 months & $\begin{array}{l}\text { Very bloody and painful. If cavernosum is hit by mistake, } \\
\text { bleeding can be very hard to stop, erectile dysfunction may } \\
\text { follow. }\end{array}$ \\
\hline $\begin{array}{l}\text { Apadravya } \\
\text { (Figure 1c) }\end{array}$ & $\begin{array}{l}\text { Vertical through the head of the penis above or through the } \\
\text { urethra }\end{array}$ & 6-12 months & $\begin{array}{l}\text { Can produce heavy bleeding. Sometimes placed more } \\
\text { proximally in the shaft of the penis. This is called a Shaft or } \\
\text { Deep Apadravya }\end{array}$ \\
\hline $\begin{array}{l}\text { Prince Albert/Reverse } \\
\text { Prince Albert } \\
\text { (Figure 1d) }\end{array}$ & $\begin{array}{l}\text { In the Prince Albert, the ring extends from urethral opening } \\
\text { downwards to the frenulum. In Reverse Prince Albert the ring } \\
\text { exits from the dorsum of the penis }\end{array}$ & 2-6 weeks & $\begin{array}{l}\text { Currently reported as the most popular penile ring. Can } \\
\text { produce intense urethral stimulation during intercourse. } \\
\text { Various objects can be attached to offer additional } \\
\text { satisfaction to female partner during intercourse }\end{array}$ \\
\hline $\begin{array}{l}\text { Frenum/Frenum } \\
\text { Ladder/Jacobs Ladder } \\
\text { (Figure 1e) }\end{array}$ & $\begin{array}{l}\text { Piercing at the center of underside of penis near glans and } \\
\text { meets shaft. Frenum Ladder is a variation where multiple barbell } \\
\text { piercings are placed on top, sides, or shaft of penis. Jacobs } \\
\text { Ladder is the dorsal equivalent to the Frenum Ladder }\end{array}$ & 3-4 months & \\
\hline $\begin{array}{l}\text { Lorum } \\
\text { (Figure 1f) }\end{array}$ & Piercing where the penis joins the scrotum & $6-8$ weeks & \\
\hline $\begin{array}{l}\text { Guiche } \\
\text { (Figure 1g) }\end{array}$ & Piercing between scrotum and anus behind the testes & $6-8$ weeks & Can be placed through anus as anal ring \\
\hline $\begin{array}{l}\text { Hafada/Pubic Piercing } \\
\text { (Figure } 1 \mathrm{~h} \text { ) }\end{array}$ & $\begin{array}{l}\text { Hafada is a superficial piercing on scrotum it does not penetrate } \\
\text { the scrotal sac. Pubic Piercing is placed at the juncture of the } \\
\text { penis shaft and pubic mound }\end{array}$ & $6-8$ weeks & \\
\hline
\end{tabular}

Table 1: Male Genital Piercings [2-5,7,9]. 
Citation: Dalke KA, Fein L, Jenkins LC, Caso JR, Salgado CJ (2013) Complications of Genital Piercings. Anaplastology 2: 122. doi: 10.4172/21611173.1000122

Page 3 of 5

\begin{tabular}{|c|c|c|c|}
\hline NAME & DESCRIPTION & HEALING TIME & ADDITIONAL INFO \\
\hline $\begin{array}{l}\text { Vertical Clitoral } \\
\text { Hood } \\
\text { (Figure 2a) }\end{array}$ & Placed above clitoris not through it. The jewelry rests under the prepuce & $6-8$ weeks & $\begin{array}{l}\text { Most popular piercing for women; produces } \\
\text { increased sexual stimulation }\end{array}$ \\
\hline $\begin{array}{l}\text { Horizontal Clitoral } \\
\text { Hood } \\
\text { (Figure 2b) }\end{array}$ & Jewelry traverses the hood tissue above clitoris & $6-8$ weeks & $\begin{array}{l}\text { Aesthetically pleasing but does not produce } \\
\text { much sexual stimulation }\end{array}$ \\
\hline $\begin{array}{l}\text { Triangle } \\
\text { (Figure 2a) }\end{array}$ & Deep piercing of the clitoral hood & 2-4 months & Intense clitoral stimulation during intercourse \\
\hline $\begin{array}{l}\text { Clitoral Body } \\
\text { (Figure 2c) }\end{array}$ & Placed directly through clitoral body & $2-6$ weeks & Much less common than clitoral hood piercings \\
\hline $\begin{array}{l}\text { Labia Majora } \\
\text { (Figure } 2 b \text { ) }\end{array}$ & Often placed on both sides for a ladder effect & $6-8$ weeks & Mostly for aesthetics \\
\hline $\begin{array}{l}\text { Labia Minora } \\
\text { (Figure 2d) }\end{array}$ & Either single or multiple rings placed & $6-8$ weeks & \\
\hline $\begin{array}{l}\text { Fouchette } \\
\text { (Figure 2e) }\end{array}$ & Similar to male guiche, positioned between back of vagina and anus & & \\
\hline $\begin{array}{l}\text { Princess Albertina } \\
\text { (Figure 2d) }\end{array}$ & $\begin{array}{l}\text { Female equivalent of the Prince Albert; the ring enters through the urethra } \\
\text { and exits between the urethral and vaginal openings }\end{array}$ & & \\
\hline $\begin{array}{l}\text { Christina } \\
\text { (Figure 2f) }\end{array}$ & Vertical piercing through the clitoral body which exits suprapubically & & \\
\hline
\end{tabular}

Table 2: Female Genital Piercings [2-5,7,9].

Complications of Male Genital Piercings

Documented complications

Bleeding [1,2]

Urethralcutaneous fistula of the glans penis [19]

Accidental trauma to neighboring anatomical structures [19]

Paraphimosis $[2-5,8,19,20]$

Priapism or penile engorgement $[2-5,8,21]$

Urethral rupture, tear, stricture, fistula $[2-4,8]$ urinary flow changes, urinary interruption, difficulty aiming and spray

Site sensitivity/skin irritation $[6,8]$

Keloid formation/scarring [1,3,5,6]

Site rips/tears [6]

Potential/speculated concerns for structural complications

Heavy bleeding if cavernosum hit by mistake [4]

Erectile dysfunction [4]

Penile fibrosis [4]

Complications of Female Genital Piercings

Documented complications

Keloid formation/scarring $[9,10]$

Clitoral hood/glans avulsion [22]

Bleeding [8]

Potential/speculated concerns for structural complications

Impeded vaginal delivery or laceration risk during delivery $[3,5]$

Difficulty inserting foley catheter [3]

Risk of tearing out during intercourse (with the Albertina) [5]

Clitoral fibrosis [5]

Numbness, parathesia [3]

General structural complications of piercings

Jewelry becoming embedded within the tissue ${ }^{20}$; frictional irritation; localized argyria; exuberant granulation tissue; lipomas; epidermal cyst formation; sarcoid granulomas; hematoma formation 1

Table 3: Documented and potential/speculated complications of genital piercings with suggested methods for repair or treatment, and general structural complications of piercings.

In males, bleeding is the major acute injury after piercing. Injury to the corpora cavernosa can cause significant bleeding. In the tip of the penis, a shunt between the corpora cavernosa and spongiosum/glans may be caused by a misplaced piercing and thus lead to significant

\section{Suggested repair or treatment of complications}

Reapproximation/repair with sutures or a cyanoacrylate tissue adhesive (ex: Dermabond $₫$,

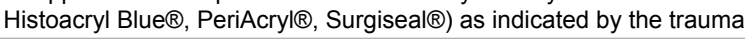

Reduction under local anesthesia or injection of prepuce with hyaluronidase Injection of sympathomimetic drug and aspiration with potential need for shunt surgery and reconstruction

Surgical repair, surgical reconstruction, dilation of urethral strictures

Use of surgical stainless steel rings

Surgical removal, repair; steroid injections

(ex: Dermabond $®$,

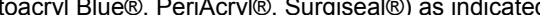

Pressure; chemical cauterization; electrical cauterization; surgical correction

Phosphodiesterase-5 (PDE-5) inhibitor; intrapenile injection (prostaglandin E1, vasodilator phentolamine); penile prosthesis; penile revascularization Removal of fibrotic tissue and placement of graft or implant if concomitant erectile dysfunction

\section{Suggested repair or treatment of complications}

Reapproximation with sutures or a cyanoacrylate tissue adhesive (ex: Dermabond $®$, Histoacryl

Pressure; chemical cauterization; electrical cauterization; surgical exploration; reconstruction Suggested repair or treatment of complications

Removal of piercing before insertion of catheter

Removal of piercing before intercourse Blue ${ }^{\circledR}$, PeriAcryl $₫$, Surgiseal $\left.{ }^{\circledR}\right)$; surgical reconstruction

bleeding acutely and later erectile dysfunction due to the inability of blood to accumulate in the corpora cavernosa. The urethra is vulnerable to fistula formation and/or stricture disease secondary to the presence of the piercing or after removal of the piercing. This may be due to acute 

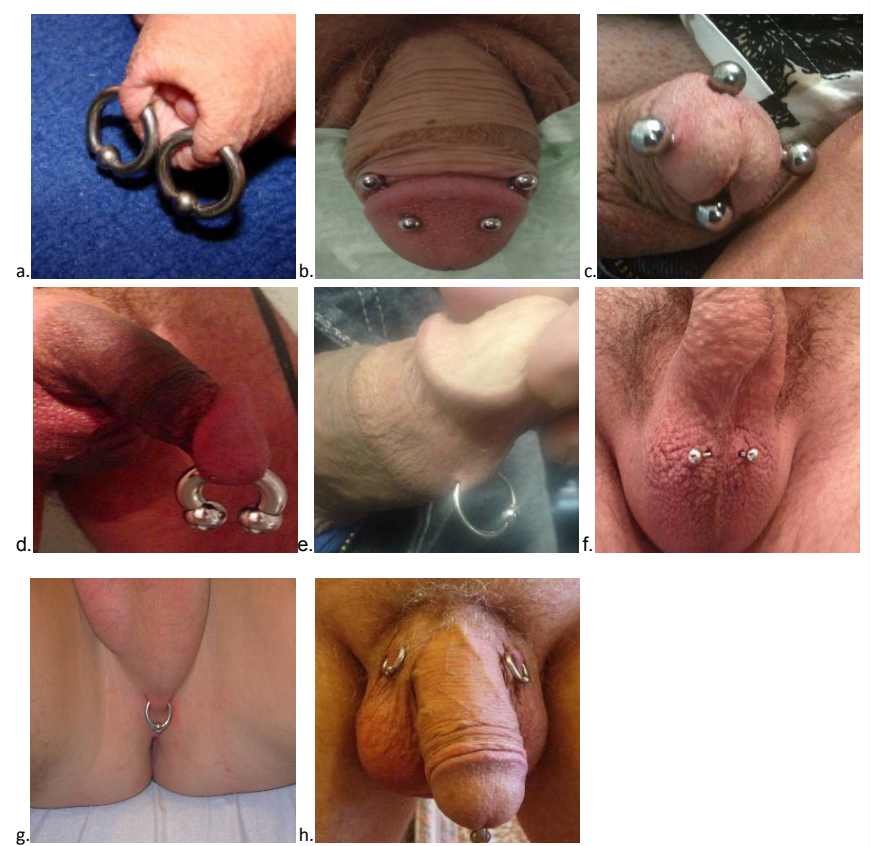

Figure 1: Male Genital Piercings.

a.Foreskin(http://www.piercing-bewertung.de/sites/default/files/imagecache/ piercing_thumbnail_square/piercings/4_3.jpg)

b. Dydoe (http://iamheadrick.com/wp-content/uploads/2012/01/head-dydoes. jpg)

c.Ampallang and Apadravyad.Prince Alberte. Frenumf.Lorem (http:// community.tribalectic.com/files/imagecache/display/files/experience_image/ jhafada2.JPG)

g.Guiche(http://www.tattoobyvladi.com/albums/Victor-piercing-x-sito/ DSCN0573.JPG )

h.Hafada (http://www.thepiercingshopoc.com/sites/default/files/styles/media gallery_large/public/HAFADA\%205.jpg)
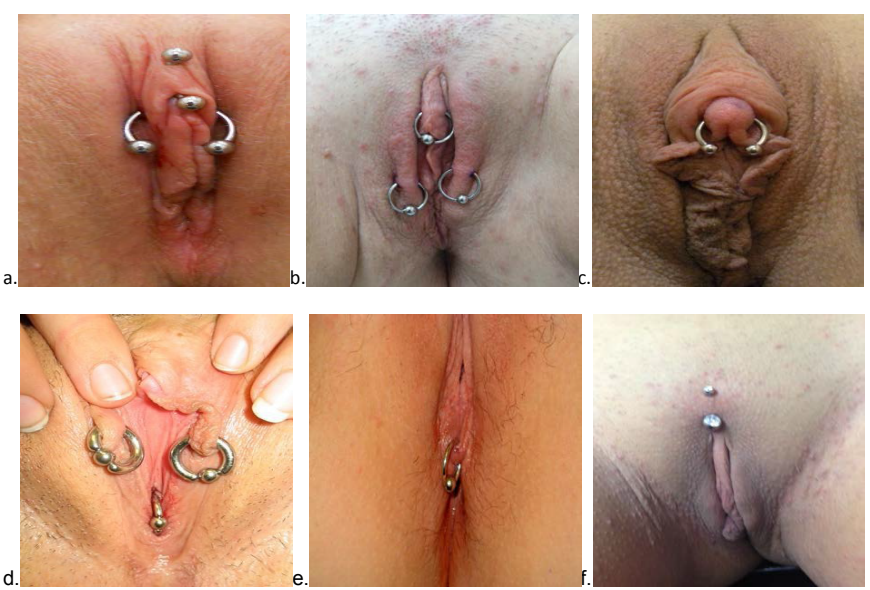

Figure 2. Female Genital Piercings.

a. Vertical clitoral hood and Triangle(http://bodypiercingroma.wordpress. com/tag/triangle-piercing/)

b. Horizontalclitoral hood and Labia majora

c. Clitoral body(http://piercingbible.com/clitoris-piercing)

d. Labia minora and Princess Albertina(http://www.tattoocolumbia.com/ piercings/piercings-by-eric/genital-piercings-2/)

e.Fouchette(http://s3.otherpeoplespixels.com/sites/23432/assets/ XJWIt2THPBvNq_ls.jpg)

f. Christina injury and inflammation, chronic irritation, or poor healing properties, i.e. keloid or granuloma formation. In uncircumcised patients, paraphimosis may occur if the patient or piercer does not return the foreskin to the natural position covering the penile glans. As is shown in Table 3, treatment of structural complications related to genital piercing are specific to the injury. Piercings resulting in site trauma or tear can require surgical repair, while others, such as priapism, can be treated medically if the patient seeks care early enough. For piercings that damage the urethra, the severity of the urethral disease determines if the patient will require reconstructive surgery to correct the injury

In females, there are some areas of overlap, such as in the potential for bleeding, keloid or scar formation, stricture, and avulsion at the piercing site. Despite these similarities, the number and variety of documented structural complications are notably fewer in women compared to men. As in men, damage to the tissue at or around the piercing site may require surgical correction (Table 3 ).

\section{Infectious Complications}

Some individuals, such as those who are immune compromised, have multiple risk factors or an increased vulnerability for acquiring infectious diseases, making it difficult to ascertain whether transmission of the infection was caused by the genital piercing, or a pre-existing condition $[2,8]$.

\section{Infections Associated with Body Piercings in General}

Risk of infection is not limited to genital piercing and can be associated with all forms of body piercing. Transmission of Hepatitis B, C, D and G has been reported, with some rare cases progressing to fatal fulminant hepatitis $[22,23]$. The possibility of transmitting HIV exists, and there have been cases reported of transmission of tetanus, leprosy, and tuberculosis after body piercings [8]. Bacterial infections with Staphylococcus aureus, Group A Streptococcus and Pseudomonas spp. are the most common following piercing. Most infections caused by body piercing are mild, localized and easily treated with topical antibacterial ointment, frequent cleansing and warm compresses with no need to remove the piercing $[5,19]$. However, the risk of cellulitis, carbuncles, impetigo, abscesses, post -streptococcal glomerulonephritis, endocarditis, as well as bacteremia and toxic shock syndrome still remains [1-3,19,20].

\section{Infections Associated Specifically with Genital Piercing}

The most common causative agents of infections caused by genital piercing are Escherichia coli, Klebsiella spp, Proteus mirabilis, Pseudomonas spp, Staphylococcus aureus, Enterococcus spp, and Staphylococcus saprophyticus [3]. While there have not been major studies, case reports, descriptive studies, and self-reporting surveys have described genital piercing-associated sexually transmitted infections (STIs) [24]. The data that have been collected challenge the assumption that individuals with genital piercings have an increased incidence of STIs [4,6]. However, an association between genital piercing and molluscum contagiosum has been reported, as well as an association between genital piercing and recurrent condyloma accuminatum caused by Human Papilloma Virus [2,6,19,20]. Penile edema (suspected to be caused by $N$. gonorrhoeae or C. trachomatis ), prostatitis, testicular infection, and Fournier's gangrene have all been reported in association with genital piercing, and squamous cell carcinoma has been diagnosed at the site of a Prince Albert's ring piercing $[3,5,25]$. The mechanisms postulated as modes of transmission include trauma, chafing, and/or fistulas, caused by genital piercings 
Citation: Dalke KA, Fein L, Jenkins LC, Caso JR, Salgado CJ (2013) Complications of Genital Piercings. Anaplastology 2: 122. doi: 10.4172/21611173.1000122

Page 5 of 5

\begin{tabular}{|l|l|}
\hline Infectious Etiology & Treatment Options \\
\hline $\begin{array}{l}\text { E. coli; Klebsiella spp; Proteus mirabilis; Staphylococcus } \\
\text { saprophyticus }\end{array}$ & Trimethoprim-sulfamethoxazole \\
\hline Pseudomonas spp & Imipenem; aminoglycosides; fluoroquinolones; third or fourth generation cephalosporins \\
\hline Staphylococcus aureus & $\begin{array}{l}\text { Clindamyicn; Trimethoprim-sulfamethoxazole; doxycycline; large abscesses or multiple lesions might } \\
\text { require incision and drainage }\end{array}$ \\
\hline Enterococcus spp & Amoxicillin; nitrofurantoin; fosfomycin; Linezolid (for resistant strains) \\
\hline Molluscum contagiosum & Generally self-resolving; can be treated with cryotherapy \\
\hline $\begin{array}{l}\text { Human Papilloma Virus-associated condyloma } \\
\text { accuminatum }\end{array}$ & $\begin{array}{l}\text { Chemical removal with podophyllin or trichloroacetic acid; Imiquimod treatment; cryotherapy; laser therapy; } \\
\text { excision }\end{array}$ \\
\hline Neisseria gonorrhoeae & Ceftriaxone + Azithromycin (for assumed concomitant Chlamydia infection) \\
\hline Chlamydia trachomatis & Azithromycin \\
\hline Fournier gangrene & $\begin{array}{l}\text { Aggressive drainage and debridement + empiric broad spectrum antibiotic therapy (such as carbapenem + } \\
\text { clindamycin) }\end{array}$ \\
\hline
\end{tabular}

Table 4: Infectious complications of genital piercings and associated treatment options.

allowing local invasion of microorganisms [24]. Genital piercings have also been noted to cause urinary tract infections [1]. Infectious complications of genital piercings can generally be treated with antibiotics (Table 4) with the possibility of incision and drainage for larger abscesses or cryotherapy for condyloma accuminatum.

\section{Partner Related Complications}

Complications of genital piercings as pertaining to the sexual partner include condoms being damaged by protruding jewelry during intercourse, swallowed piercings causing choking and aspiration, trapping of piercings between the partner's teeth, teeth-chipping, postcoital bleeding, and loss of jewelry $[2,5,8,19,20]$.

\section{Conclusions}

While genital piercing is not a new phenomenon, it appears to be an increasingly common trend. Healthcare providers need to be aware of this practice as well as its complications and recognize the importance of conducting a thorough sexual history so that appropriate counseling and treatment can be offered. Medical documentation of genital piercings and their complications will provide data for further investigation.

\section{Acknowledgements}

No potential conflicts of interest relevant to this article were reported.

\section{References}

1. Waugh M (2007) Body piercing: where and how. Clin Dermatol 25: 407-411.

2. Anderson WR, Summerton DJ, Sharma DM, Holmes SA (2003) The urologist's guide to genital piercing. BJU Int 91: 245-251.

3. Stirn A (2003) Body piercing: medical consequences and psychological motivations. Lancet 361: 1205-1215.

4. Hogan L, Rinard K, Young C, Roberts A, Armstrong M, et al. (2010) A crosssectional study of men with genital piercings. Br J Med Pract 3: 315

5. Nelius T, Armstrong ML, Rinard K, Young C, Hogan L, et al. (2011) Genital piercings: diagnostic and therapeutic implications for urologists. Urology 78 : 998-1007.

6. Caliendo C, Armstrong ML, Roberts AE (2005) Self-reported characteristics of women and men with intimate body piercings. J Adv Nurs 49: 474-484.
7. Marenzi B (2004) Body piercing: a patient safety issue. J Perianesth Nurs 19 4-10.

8. Meltzer DI (2005) Complications of body piercing. Am Fam Physician 72: 20292034.

9. Miller L, Edenholm M (1999) Genital piercing to enhance sexual satisfaction Obstet Gynecol 93: 837

10. Lombroso-Ferro G (1972) Criminal Man According to the Classification of Cesare Lombroso. Montclair, NJ: Patterson Smith.

11. Fiumara NJ, Eisen R (1983) The titivating penile ring. Sex Transm Dis 10: 43 44.

12. Hansen RB, Olsen LH, Langkilde NC (1998) Piercing of the glans penis. Scand J Urol Nephrol 32: 219-220.

13. Buhrich N (1983) The association of erotic piercing with homosexuality sadomasochism, bondage, fetishism, and tattoos. Archives of Sexual Behavior 12: $167-171$

14. Willmott FE (2001) Body piercing: lifestyle indicator or fashion accessory? Int J STD AIDS 12: 358-360.

15. Young C, Armstrong ML, Roberts AE, Mello I, Angel E (2010) A triad of evidence for care of women with genital piercings. J Am Acad Nurse Pract 22: 70-80.

16. Millner VS, Eichold BH 2nd, Sharpe TH, Lynn SC Jr (2005) First glimpse of the functional benefits of clitoral hood piercings. Am J Obstet Gynecol 193: $675-676$.

17. Ferguson $\mathrm{H}$ (1999) Body piercing. BMJ 319: 1627-1629.

18. Reader Survey (1994) Body Art 34-36.

19. MacLeod TM, Adeniran S (2004) An unusual complication of penile piercing: a report and literature review. Br J Plast Surg 57: 462-464.

20. Takahashi S, Hirano Y, Kawamura T, Homma Y (2013) Intraurethra condylomata acuminata associated with genital piercings. Int J STD AIDS.

21. Slawik S, Pearce I, Pantelides M (1999) Body piercing: an unusual cause of priapism. BJU Int 84: 377.

22. Berger A, Worly B (2013) Clitoral avulsion successfully repaired with 2-octylcyanoacrylate. J Sex Med 10: 1889-1892.

23. Das G, Rawal N, Bolton LM (2005) The case of the missing "Prince Albert". Obstet Gynecol 105: 1273-1275.

24. Hounsfield V, Davies SC (2008) Genital piercing in association with gonorrhoea, chlamydia and warts. Int J STD AIDS 19: 499-500.

25. Edlin RS, Aaronson DS, Wu AK, Blaschko SD, Yang G, et al. (2010) Squamous cell carcinoma at the site of a Prince Albert's piercing. J Sex Med 7: 2280-2283. 